\title{
STORED NUTS CASTANOPSIS CUSPIDATA AS A FOOD RESOURCE OF NESTLING VARIED TITS PARUS VARIUS
}

\author{
Hiroyoshi HiguchI
}

Laboratory of Forest Zoology, Faculty of Agriculture, The University of Tokyo, Tokyo 113

The feeding and breeding habits in the Miyake Island population of the Varied Tit Parus varius in comparison with those of a mainland population were reported in my earlier papers (HIGUCHI, 1975, 1976a). Since that time, an interesting fact was discovered, this being that the island population uses the nuts stored in autumn and early winter not only as the principal food in winter but also as food for raising nestlings and fledglings in the breeding season. Such habits are not known in the mainland population of the Varied Tit and other species of tits, excepting the Siberian Tit Parus cinctus which gives insect larvae stored several days before to the nestlings (HAFTORN, 1973).

The purpose of this paper is to report what proportion of the food brought to nestlings consisted of stored nuts in this island population of the Varied Tit. The nut storing habit of the island population is described briefly in Appendix, since the subject has previously been treated only in Japanese.

\section{METHODS}

This study was carried out at Yakushi-do and Tairo-ike on Miyake I. The geography, climate and vegetation of the study areas is described in my earlier papers (HiGUCHI , 1975, 1976ab).

The Food items brought to young were identified by an analysis of photographs obtained by using a $300 \mathrm{~mm}$ telephoto lens from a blind set about two meters from occupied nest boxes. Because precise identification was not always possible by this method, only four categories of food items were recognized: adult lepidoptera, larval lepidoptera, kernels of stored nuts, and "others". These four categories could be easily distinguished except when the head or bill of the parent bird had already entered the hole of the nest box. All nut kernels brought to the young were those of Castanopsis cuspidata. Because the Castanopsis nuts containing a kernel are not availble in the breeding season, these kernels are thought to be obtained from the nuts stored in the previous winter.

The Varied Tits often bring more than two larvae or adult insects at a single feeding. Therefore the proportion of each category of food is analyzed in two ways: by the frequency of feeding and by the frequency of number of food items. The nut kernel brought at a single feeding must necessarily have been that of one nut, since the birds probably cannot break open a second nut while holding another kernel in the bill.

The field observations were carried out in the spring of 1975 and 1976. In 1975 one nest box, with four young, was under observation from May 1 to May 13. At this nest, the total number of photographs showing identifiable food items was 166 (Table 1). In 1976 five nest boxes, with two or four young, were observed from April 27 to May 13. For these, the total number of usable photographs was 258 (Table 2).

\section{RESUlts and Discussion}

The results are shown in Table 3 and Table 4 . In both years the frequency of feeding of nut kernels was low, about 5-8 per cent of the total number of feeding trips and about 3-5 per cent of the total number of food items.

There is a small difference in these figures in relation to pair, age of young, or year, but the data obtained were not sufficient to permit further analysis. However, comparing the rate 
Table 1. Observations on food brought to the nestling Parus varius in 1975

\begin{tabular}{ccccccc}
\hline \hline Nestbox* & $\begin{array}{c}\text { Date of } \\
\text { observation }\end{array}$ & $\begin{array}{l}\text { Number } \\
\text { of young }\end{array}$ & $\begin{array}{c}\text { Days after } \\
\text { hatching }\end{array}$ & $\begin{array}{c}\text { Time of } \\
\text { observation }\end{array}$ & $\begin{array}{c}\text { Number of } \\
\text { photographs } \\
\text { obtained }\end{array}$ & $\begin{array}{c}\text { Number of } \\
\text { photographs } \\
\text { used for food } \\
\text { analysis }\end{array}$ \\
\hline Y-6 & May 1 & 4 & 2 & $9: 30-12: 40$ & 14 & 6 \\
Y-6 & May 5 & 4 & 6 & $10: 00-12: 05$ & 15 & 11 \\
Y-6 & May 11 & 4 & 12 & $9: 15-16: 05$ & 89 & 71 \\
Y-6 & May 13 & 4 & 14 & $7: 30-14: 45$ & 90 & 78 \\
\hline
\end{tabular}

Table 2. Observations on food brought to the nestling Parus varius in 1976

\begin{tabular}{lcccrcc}
\hline \hline Nestbox* & $\begin{array}{c}\text { Date of } \\
\text { observation }\end{array}$ & $\begin{array}{l}\text { Number } \\
\text { of young }\end{array}$ & $\begin{array}{c}\text { Days after } \\
\text { hatching }\end{array}$ & $\begin{array}{c}\text { Time of } \\
\text { observation }\end{array}$ & $\begin{array}{c}\text { Number of } \\
\text { photographs } \\
\text { obtained }\end{array}$ & $\begin{array}{c}\text { Number of } \\
\text { photographs } \\
\text { used for food } \\
\text { analysis }\end{array}$ \\
\hline Y-8 & April 27 & 4 & 2 & $10: 00-15: 00$ & 23 & 19 \\
Y-8 & April 28 & 4 & 3 & $9: 25-11: 45$, & 33 & 26 \\
Y-8 & May 4 & 4 & 9 & $10: 00-15: 00$ & 79 & 59 \\
Y-6 & May 1 & 4 & 3 & $13: 10-17: 10$ & 28 & 22 \\
Y-11 & May 13 & 2 & $7-8$ & $8: 05-15: 10$ & 96 & 64 \\
T-7 & May 5 & 2 & 11 & $9: 25-15: 00$ & 51 & 43 \\
T-10 & May 5 & 4 & 12 & $11: 35-14: 45$ & 48 & 25 \\
\hline
\end{tabular}

* Y stands for the Yakushi-area and T for the Tairo-area.

which stored nut kernels were brought and the rate which the other food was brought, the total difference between 1975 and 1976 is not significant $\left(\chi_{0}^{2}<\chi_{1}^{2}[0.10]\right)$ either in the frequency of number of food items or in the frequency of feeding.

That there was little difference between 1975 and 1976 in the utilization of stored nuts is interesting, because the crop of Castanopsis cuspidata was much better in the autumn of 1975 than in the autumn of 1974 (HigUCHI, 1975). Besides, no significant difference was found in the clutch size in 1975 and 1976 ( $t$-test, $t=0.00<t\left[P_{0.90}, d . f=23\right]$ ). This differs from the observations on the Nutcracker Nucifraga caryocatactes in Sweden, in which the clutch size was large when the crop of hazelnuts was good in the previous autumn (SWANBERG , 1951).

The reason why the crop of Castanopsis nuts did not affect the feeding and clutch size of the Varied Tit on Miyake Island is not well understood. However, The stored nuts are the main food of the Varied Tits in winter and a large part of them must probably be used up in this season. Therefore, few nuts will be available in the breeding season, and this may not cause large annual differences in the frequency of use of stored nuts in the breeding season, and also in clutch size. In the Nutcrackers, stored nuts are an important food supply both in winter and in breeding season (SWANBERG, 1951; GOODWIN, 1975).

In any case, stored nuts do not appear to play an important part in rearing the young in the Miyake Island population of the Varied Tit. As shown in Table 3 and Table 4, the main food brought to the young was the larvae and adults of insects, as in the mainland population of the Varied Tit. In this regards, it is worth noting that more larval lepidoptera were brought to the young during the first week åfter hatchng, after which more adult lepidoptera were brought. In comparison with the mainland population (WoN, et al., 1965: HigucHI, unpublished), more adult insects were brought to the young in the Miyake island population. The proportion of adult insects was 13.9 per cent in Korea (WoN, et al., 1965), mroe than 45 per cent in the present study on Miyake I. 
Table 3. Food of the nestling Parus varius in 1975

\begin{tabular}{|c|c|c|c|c|c|c|c|c|c|c|c|}
\hline \multirow{3}{*}{ Date } & \multirow{3}{*}{$\begin{array}{c}\text { Days } \\
\text { after } \\
\text { hatching }\end{array}$} & \multirow{2}{*}{\multicolumn{2}{|c|}{ Number of }} & \multicolumn{8}{|c|}{ Proportions of foods (\%) } \\
\hline & & & & \multicolumn{2}{|c|}{$\begin{array}{c}\text { Adult } \\
\text { lepidoptera }\end{array}$} & \multicolumn{2}{|c|}{$\begin{array}{c}\text { Larval } \\
\text { lepidoptera }\end{array}$} & \multicolumn{2}{|c|}{$\begin{array}{l}\text { Kernels of } \\
\text { stored nuts }\end{array}$} & \multicolumn{2}{|c|}{ Other } \\
\hline & & feeding & $\begin{array}{l}\text { tood } \\
\text { items }\end{array}$ & $\begin{array}{c}\text { Freq. } \\
\text { of } \\
\text { feeding }\end{array}$ & $\begin{array}{l}\text { Freq. } \\
\text { of food } \\
\text { items }\end{array}$ & $\begin{array}{c}\text { Freq. } \\
\text { of } \\
\text { feeding }\end{array}$ & $\begin{array}{l}\text { Freq. } \\
\text { of food } \\
\text { items }\end{array}$ & $\begin{array}{c}\text { Freq. } \\
\text { of } \\
\text { feeding }\end{array}$ & $\begin{array}{c}\text { Freq. } \\
\text { of food } \\
\text { items }\end{array}$ & $\begin{array}{l}\text { Freq. } \\
\text { of } \\
\text { feeding }\end{array}$ & $\begin{array}{l}\text { Freq. } \\
\text { of food } \\
\text { items }\end{array}$ \\
\hline May & 2 & 6 & 6 & 0.0 & 0.0 & 83.3 & 83.3 & 0.0 & 0.0 & 16.7 & 16.7 \\
\hline May 5 & 6 & 11 & 11 & 9.1 & 9.1 & 54.5 & 54.5 & 18.2 & 18.2 & 18.2 & 18.2 \\
\hline May 11 & 12 & 71 & 110 & 42.3 & 40.9 & 29.6 & 38.2 & 8.5 & 5.5 & 19.7 & 15.5 \\
\hline May 13 & 14 & 78 & 120 & 57.7 & 60.8 & 20.5 & 22.5 & 6.4 & 4.2 & 15.4 & 12.5 \\
\hline \multicolumn{2}{|c|}{ Total } & 166 & 247 & 45.8 & 48.2 & 28.9 & 32.4 & 8.1 & 5.3 & 17.5 & 14.2 \\
\hline
\end{tabular}

Table 4. Food of the nestling Parus varius in 1976

\begin{tabular}{|c|c|c|c|c|c|c|c|c|c|c|c|}
\hline \multirow{3}{*}{ Date } & \multirow{3}{*}{$\begin{array}{c}\text { Days } \\
\text { after } \\
\text { hatching }\end{array}$} & \multirow{2}{*}{\multicolumn{2}{|c|}{ Number of }} & \multicolumn{8}{|c|}{ Proportions of foods $(\%)$} \\
\hline & & & & \multicolumn{2}{|c|}{$\begin{array}{c}\text { Adult } \\
\text { lepidoptera }\end{array}$} & \multicolumn{2}{|c|}{$\begin{array}{c}\text { Larval } \\
\text { lepidoptera }\end{array}$} & \multicolumn{2}{|c|}{$\begin{array}{l}\text { Kernels of } \\
\text { stored nuts }\end{array}$} & \multicolumn{2}{|c|}{ Other } \\
\hline & & feeding & $\begin{array}{l}\text { food } \\
\text { items }\end{array}$ & $\begin{array}{c}\text { Freq. } \\
\text { of } \\
\text { feeding }\end{array}$ & $\begin{array}{l}\text { Freq. } \\
\text { of food } \\
\text { items }\end{array}$ & $\begin{array}{c}\text { Freq. } \\
\text { of } \\
\text { feeding }\end{array}$ & $\begin{array}{l}\text { Freq. } \\
\text { of food } \\
\text { items }\end{array}$ & $\begin{array}{c}\text { Freq. } \\
\text { of } \\
\text { feeding }\end{array}$ & $\begin{array}{l}\text { Freq. } \\
\text { of food } \\
\text { items }\end{array}$ & $\begin{array}{c}\text { Freq. } \\
\text { of } \\
\text { feeding }\end{array}$ & $\begin{array}{l}\text { Freq. } \\
\text { of food } \\
\text { items }\end{array}$ \\
\hline April 27 & 2 & 19 & 20 & 31.6 & 30.0 & 63.2 & 65.0 & 0.0 & 0.0 & 5.3 & 5.0 \\
\hline April 28 & 3 & 26 & 32 & 30.8 & 28.1 & 69.2 & 71.9 & 0.0 & 0.0 & 0.0 & 0.0 \\
\hline May 1 & 3 & 22 & 30 & 31.8 & 23.3 & 54.5 & 63.3 & 0.0 & 0.0 & 13.6 & 13.3 \\
\hline May 13 & $7-8$ & 64 & 105 & 34.4 & 24.8 & 46.9 & 63.8 & 3.1 & 1.9 & 15.6 & 9.5 \\
\hline May 4 & 9 & 59 & 81 & 55.9 & 54.3 & 13.6 & 18.5 & 16.9 & 12.3 & 13.6 & 14.8 \\
\hline May 5 & 11 & 43 & 61 & 74.4 & 72.1 & 20.9 & 24.6 & 2.3 & 1.6 & 2.3 & 1.6 \\
\hline May & 12 & 25 & 39 & 64.0 & 56.4 & 32.0 & 41.0 & 0.0 & 0.0 & 4.0 & 2.6 \\
\hline \multicolumn{2}{|c|}{ Total } & 258 & 368 & 48.1 & 42.9 & 37.6 & 45.7 & 5.0 & 3.5 & 9.3 & 7.9 \\
\hline
\end{tabular}

\section{ACKNOWLEDGEMENT}

I am deeply indebted to Mr. Shigeto KoIKe for his assistance in the field work. A great debt is due to Dr. Storrs L. Olson of the Smithsonian Institution, Dr. Robert B. PAYNE of the University of Michigan, and Dr. Hiroyuki MorIoKa of the National Science Museum in Japan for reading and criticizing the draft of this paper.

\section{Literature Cited}

Goodwin, D. 1976. Crows of the world. Ithaca, Cornell University Press.

Haftorn, S. 1973. A study of the Siberian Tit Parus cinctus during the breeding season. Sterna, 12:91-155.

Higuchi, H. 1975. Comparative feeding ecology of two geographical forms of the Varied Tit, Parus varius varius in southern Izu Peninsula and P. v. owstoni in Miyake I. of the Izu Is. Tori, 24: 15-28.

HiguCHI, H. 1976a. Comparative study on the breeding of mainland and island subspecies of the Varied Tit, Parus varius. Tori, 25:11-20.

Higuchi, H. 1976b. Home range and pair duration in the Varied Tit, Parus varius. Tori, 25:6980. 
Swanberg, P. O. 1951. Food storage, territory and song in the Thick-billed Nutcracker. Proc. $X$ Int. Orn. Cong. 1950:545-554.

WoN, P., S. KIM, and C. KIM. 1965. Breeding biology and chick food of Varied Tit Parus varius in Korea. Misc. Rep. Yamashina Inst. Ornith., 4:198-207.

Appendix: Storing habits of nuts in the Miyake Island population of the Varied Tit (based on HigUCHI, 1975).

Actual storage can be observed during late August to February, and the period in which storage activity is greatest is October to November. Stored foods are the nuts of Castanopsis cuspidata, Styrax japonica, and Camellia japonica. Of these, the food most often stored is the nuts of Castanopsis cuspidata, except when the nuts of Styrax japonica is abundant and more easily available.

The storing behaviour is as follows. If the nut is that of Castanopsis or Styrax, which have an obtuse and a pointed end, it is held in the bill with the pointed end directed forward. Then the nut is forced into a hiding place such as a dead tree, the crevice of a trunk, or the root of a tree. Next, the obtuse end is knocked on by the bill to push it in deep, and finally a chip of wood or a clod of earth is stuffed into the stored place. Only one nut is hidden in each stored place, and in no case were more than two nuts observed to be stored in a single place.

The use of the stored nuts begins in late December at latest, and the stored nuts are the main food in winter. The latest month when the use of nuts is observed is May. Sometimes only part of nut is eaten and then the rest is restored in a different place.

\title{
ヤマガラの蓶の食物中に含まれている眝蔵食物の割合
}

\author{
樋口広芳
}

束京大学農学部森林動物学教室

伊豆諸島三宅島飞すむヤマガラについて，1975 年と1976 年の繁殖期に，親鳥が紧内倠にるってく る食物の中に秋冬季に聍劣ておいた木の実がどの位含まれているかる調べた。食物の確認は，巣箱の 近くのブラインドの中から撮影した写真に基づいて行なった。得られた結果は次のと怙りである。

1) 雅峙ってきた木の実の中味はすくて，スダジイ実の中味と認められた。そして，これらは, 常態ではこの時期に得られるものではないので，すべて秋冬季に眝えておいたすのであると考えられ た。

2 ）雄に与光る食物中に占める貯蔵食物の割合は，運搬回数によっても運搬個数に基ついても，調 查棇数の $5 \%$ 前後にず゙なかった。したがって，貯藏食物がひなの生带に大きな役割を果したとは考 えられない。

3 ) 前年秋のシイの実のなり具合がよくながった 1975 年と，よかった 1976 年とでは，貯藏食物の 占める割合に有意な差は認められなかった。

4 ) その原因は，この島のヤマカラでは秋に貯えておいたシイの実の大部分を冬季に利用してしま らため，觹を育てる時期には年による著しい違いをるたらす程多くの実が残っていないらしい，とい らことにあると考えられた。 